\title{
Influence of Social Simulation Learning Strategy in Improving Social Intelligence and Talking Children in Raudhatul Athfal Jamiyatushalihin Medan
}

\author{
Anisah $^{1}$, Khadijah $^{2}$, Akmal Walad Ahkas 2 \\ ${ }^{I}$ Magister Program of Islamic Education Departement, Universitas Islam Negeri Sumatera Utara (UINSU), \\ Medan, Indonesia \\ ${ }^{2}$ Islamic Education Departement, Universitas Islam Negeri Sumatera Utara (UINSU), Medan, Indonesia
}

\begin{abstract}
This study aims to uncover and explain and know: (1) the effect of social simulation learning strategies on children's social intelligence in Raudhatul Athfal Jamiyatushalihin Medan, (2) the effect of social simulation learning strategies on children's speaking in Raudhatul Athfal Jamiyatushalihin Medan, and (3) the influence of social simulation learning strategies on social intelligence and children's talking together at Raudhatul Athfal Jamiyatushalihin Medan. The research method used is quantitative with an experimental approach. The research sample consisted of two classes each one experimental class and one control class. The instrument used in the study was observation and documentation. The analysis technique used is analysis of variance The research findings show: (1) the influence of social simulation learning strategies on children's social intelligence in Raudhatul Athfal Jamiyatushalihin Medan, (2) there is an influence of social simulation learning strategies on children's speaking in Raudhatul Athfal Jamiyatushalihin Medan, and (3) there is an influence on simulation learning strategies social towards social intelligence and talking to children together in Raudhatul Athfal Jamiyatushalihin Medan.
\end{abstract}

Keywords

social simulation; social

intelligence; talking children

\section{Introduction}

Early childhood education is implemented so that children's social intelligence and speech develop optimally is a concern. Early age is an age where children will very easily receive stimuli from their environment. The proper treatment of the environment is expected to bring positive changes to its development.

But unfortunately, education is often the way to build intelligence, it actually becomes ineffective because it only focuses on one side. Like educating children cognitively. Likewise with learning media that almost every day uses audio visual without involving children as objects in learning so that the social and speaking aspects of children lack the right portion, because children only wait for show after show. Furthermore, children are presented gadgets at home by parents as applications follow technological advances, so children are increasingly blind to socialize and poor vocabulary in speaking, because they are not trained in everyday life.

The facts show that the activities in Raudhatul Athfal Jamiyatushalihin pay less attention to aspects of social development and speaking of children, generally they are very focused on cognitive development aspects and are really excessive because at an early age, children have been required to perform tasks that are academic even almost every Children's day at Raudhatul Athfal gets homework from school. 


\section{Review of Literature}

Patmonodewo (2003: 112) explains that Raudhatul Athfal gives children the possibility to develop all aspects of their development fostering good traits and habits and fostering the basic awareness needed for learning in the next class.

Therefore in order to lay the foundation towards the development of attitudes, knowledge, skills and creativity of children, the abilities that must be mastered by students as expressed by Moeslichatoen (2004: 77), namely: (1) developing into an independent person, ( 2) learn to give, share and get affection, (3) develop self-control, (4) learn various roles of people in society, (5) learn to get to know each other's body, (6) learn to master fine motor skills and rough, (7) learn to recognize the physical environment and control, (8) learn to master new words to understand children or others, and (9) develop positive feelings in dealing with the environment.

Pratisti (2008: 64) explains that aspects of child development that must be developed include three aspects, namely: (1) physical aspects, (2) mental psychological aspects and (3) social aspects. Physical aspects can be seen through the growth of bones, muscles, nervous system and body organs. Mental psychological aspects include sustainable mental growth that can be seen through increased ability to solve problems and the ability to produce ideas. While the social aspect is the child's ability to be able to adapt to the environment or adjust to the needs and demands of the surrounding social environment.

Therefore, learning that is carried out for kindergarten children must be carried out taking into account the characteristics of children, in this case Tangyong (2009: 74) explains that the characteristics of kindergarten age children are: (1) each child is unique, children develop according with their respective tempo and speed, (2) the child develops through several stages and each chronological increase in age displays a characteristic developmental trait and (3) each child is an active student. Learning for children is everything they do while playing is a vehicle for learning and working for children. For that environment that provides a lot of mental stimulation can improve children's learning abilities.

Sudjana (2002: 112) suggests his opinion that simulation is a snapshot of a real life situation that is raised into learning activities. Furthermore Sudjana (2002: 112) explains that there are two things that must be considered in the simulation, namely: (1) simulations are arranged simply and can be carried out by students, and (2) based on the needs and goals stated by students.

Suparman (2012: 257) states that the simulation is displaying symbols or equipment that replace the actual process, event, or object. In simulation learning children can do the following things: Trying to position themselves or play a role as a certain figure or person, for example as a hero, farmer, police, engineer, pilot, doctor, teacher, and children are trained to appreciate their services and roles. Acting as objects, for example, pretending to be traffic signs, trains, cars, mountains, trees, wind, clouds and so on.

Dimyati and Mudjiono (2002: 80) suggest that simulation is a learning strategy, this format occurs when teaching and learning that shows the existence of fake behavior from the people involved or imitating the situation (in the form of processes or equipment) in such a way that people are involved in understanding the concept, principles, certain skills or attitudes and values therein. The simulation must take place in the process of activities that give rise to and produce an effective domain, such as fun, exciting, sad, touched, sympathetic, solidarity, mutual cooperation and so on.

Ahmadi (1990:85) explains some of the teacher's roles that must be performed in carrying out simulations as follows: (1) explains, the teacher can explain modestly to the child and the child must understand the rules between simulation activities, (2) supervisors, 
the teacher forms groups and dividing children into groups or roles according to their abilities and desires. The teacher must oversee the child's participation in the simulation game, here the teacher, (3) acts as a supervisor or referee who organizes the rules of the game to be obeyed by the child, (4) trains, where the teacher acts as a coach who gives instructions to the child so they can play well, and (5) lead the discussion, during the game the teacher will lead the class in an atmosphere of discussion. For example, discussing children's responses and difficulties encountered.

Ahmadi (1990:34) also argues that the simulation learning strategy has several things that can increase the activeness of children in the teaching and learning process, among others: (1) simulation is a form of teaching technique that is oriented to the activeness of students in teaching in class, both teachers or children take the part in it, (2) simulation is generally problem solving which is very useful for training children to take interdisciplinary approaches in learning, (3) besides that they can practice skills relevant to people's lives, and (4) simulation is a teaching strategy that is dynamic in the sense that it is very suitable for dealing with situations that change and requires flexibility in thinking and providing answers to circumstances that are rapidly changing.

Social intelligence is the ability of children's behavior in adjusting to the rules of the society where the child is located. Social intelligence is obtained by children through maturity and learning opportunities from various responses to themselves. For young children, play activities become a social function for children to develop. A good and healthy social order can help children in developing positive self-concept attitudes that make the development of children's socialization more optimal. This has been widely explained by experts.

Hurlock (1978: 261) suggests that from the age of 2 to 6 years children learn to do social relations and associate with people outside the home environment, especially with children of the same age. Children learn to adjust and work together in play activities.

Chaplin (2004) states that "the ability to socialize is a form of behavior, actions and attitudes displayed by individuals when interacting with others accompanied by accuracy and speed so as to provide comfort for those around them. Muhibin (1995) states that the ability to socialize is a process of social self-formation that is personal in the family, culture, nation and so on.

Hurlock (1978) states that the ability to socialize is the acquisition of the ability to behave in accordance with social guidance. Socialization is the ability to behave according to social norms, values or expectations. Akhmadi (1984: 9) explains that speaking is "as a skill of producing an articulation sound system current to convey the wants, needs, feelings and desires to others.

Laksamana (1982:25) states that speaking is an act that produces language to communicate as one of the basic skills in language. While Tarigan (2008: 16) states that speaking is the ability to say articulation sounds or words to express, express, and convey thoughts, ideas and feelings.

Furthermore Kartini (1985:7) argues that speaking is an event of conveying one's intentions, ideas, thoughts, feelings to others using spoken language so that the intent is understood by others. Tarigan (2008: 3) mentions the definition of speaking as a language skill that develops in a child's life, which is only preceded by listening skills, and it is during this time that the ability to speak or speak is learned.

Brooks (1964:134) explains speaking and listening are direct two-way communication activities and face to face communication. Moris and Novia (2002) state that speaking is "the ability to pronounce articulation sounds or words to express, express and convey thoughts, ideas and feelings. 


\section{Research Methods}

The research method used is quantitative with an experimental approach. The research sample consisted of two classes each one experimental class and one control class. The instrument used in the study was observation and documentation. The analysis technique used is analysis of variance.

\section{Discussion}

Necessarily, reflective practice can lead the teachers to be critical to their practice. However, he/she must take to an account of TPACK as the framework to be effective in teaching using technology. Concerning some aspects of TPACK, the integration between content, pedagogy, and technology. The interviews analysis focused on investigating how reflection helped the participants consider each element in TPACK; meanwhile, the reflective journals focused in what way the in-service teachers scrutinizing their perceptions with technology adoption by looking at the facets of pedagogy, content and technology.

First, the participants started to recognize the essential relation between technology and pedagogy. The participants elaborated their views or their reasons of the reflection advantageousness for technology integration in case of their teaching practice to grasp how reflection helped the participants develop TPACK. There are some perspectives described by the participants about how far they have already implemented technology integration in the lens of the TPACK framework. From the interviewed taken by both of the participants, the participants thought about the past experienced of their implementation.

Last year, I still did not understand in utilizing technology effectively by thinking about its relationship to pedagogy and material, so it needs to be fixed again, especially the material. Because the material was still not as deep as needed. Yesterday I was more concerned with using technology. It might be $40 \%$ technology, $30 \%$ content, and the rest was pedagogical. So it is not too pedagogy. So pedagogy might be a bit less balanced. (Juna, 2019).

From Juna's reflection about his experience in implementing TPACK as a framework, Juna elaborated on how far that he has implemented a TPACK framework on his technology integration in the classroom. From his statement, he focused on technological needs (TK). Meanwhile, he stated that pedagogy or how he brought the technology into the classroom in specific material (PCK) is only the rest of TK. A consideration in technological needs for specific materials showed that he could recognize the elements needed in technology integration by rethinking about his experience. The narrative revealed that reflection inservice EFL teachers helped them to develop their TPACK implementation.

Meanwhile, from Ferni, TK is the element that needs to be improved; here is Ferni narrative:

I am still less in an exploration of technology. I need to have a willingness to explore if I want to improve TPACK. It is sometimes a trial and error. It means that if I get a brilliant idea, I need to run the idea first. Well, I rarely find professional development workshops, especially in technology usage, which means exploring it, for example, what should I do or how should I do is still lack of trial. In my experience, technology in learning, if we have not tried it ourselves, we cannot use the idea. For example, I once made a quiz using Kahoot, oh this is good, it is using Kahoot. Because I have tried it already, but if someone who has not tried Kahoot, they cannot use Kahoot. Even though it is entertaining. So I do not explore because I still have a lack of understanding of IT. (Ferni,2019) 
Ferni, in her experiences, stated that technological knowledge is the essential element of the TPACK framework. To understand the development of IT, so that she can get the appropriate technology for the materials, she said that technology exploration is needed. In her example, she mentioned Kahoot as the technology which is integrated into the content or assessment. Her statement indicates that she believed between technology and content integration needs exploration of technology first before TK (Park \& Oliver, 2008). It is derived through study and research on experienced teachers in high school, stating that PCK is indeed a body of knowledge that involves both comprehension and implementation. The teachers reconstructed and combined various PCK elements by reflection-in-action (during teaching) and reflection-on-action (after teaching).

She reflected the context of specific workshops or the trial or error itself to make a fresh idea. This study points to the need for looking more closely into the relationship between teachers' deficit theorizing related to their reflection towards the technology use. Findings from this work demonstrated that teachers acquired TPACK, but many of them had difficulty applying it in action in innovative ways for the student as cited on So, et al., 2015, it may be caused by the different factors of applying technology between the teacher and the student. Other researchers have also distinguished between the knowledge that teachers possess and the knowledge they use in action (Doering et al., 2009).

Secondly, the teachers were mostly confident about technology use in classrooms. They started to understand the complexity of technology integration in the local curriculum. For example, Ferni concerns the materials and students' life.

What kind of things that I can use, for example, when I want to use those videos as the activity, so I have to find some in TED-Ed. I will find different kinds of videos. Then, it is about the students' life. So I usually create a project that is in line with the students' life. When we have to decide what the students' should do, like in bullying, they can see bullying around their life. So after that, I always try to relate the activity to the students' life. (Ferni,2019).

She believed learning a foreign language is not only talking about the theories and projects. It is about how the project itself can relate to the student's life. The teachers may be easy to find a source to integrate their knowledge on content and technological aspects, but in this case, to combine between the goals of curriculum and students' life is another challenge for the teachers not easy to pick a source and let it go without meaning. Further, she describes her concerns on making a video as a simple thing means that doing a project to combine between the technology and context might make the students confused. She mentioned that technology could be used to teach a particular material or topic. From Schmidt et al. (2009), this relates to the awareness of technology and content knowledge (TCK), then she told how and why she utilized technology appropriately with a particular strategy. She decided to simplify her instruction to make students did the projects; in this case, her pedagogy aspects are elaborated as a challenge.

I should think about what the students can do dealing with the projects. For example, when I ask them to make tips in the form of video, I have to consider making a video in a simple thing considering the student's understanding and using the time effectively. (Ferni, 2019)

Juna mentioned a similar point of view in his reflection about the positive view of technology media in the classroom. He reflected on the local curriculum affected in the use of technology decisions. Meanwhile, he elaborated that appropriate technology usage affects pedagogy effectiveness.

At the end of the lesson, I realized that I positively agree that technology helps me to improve my time efficiency. This happened when I applied poetry maker and made it into a video, so they need to upload it online. I did not need work hours to collect their work, but they can collect it for twenty-four hours! Somehow, in poetry maker application, I need to 
adjust the topic closer to the local topic because online application seems to have a western curriculum (Juna, 2019)

The effectiveness is in the form of time management for the assesemnet process. He mentioned that he realized in the end of the lesson. It means that in the end of the lesson he rethinking about teaching and learning process. Similar to Ferni's reflection, Juna also emphasized to the time management effectiveness. Juna's narrative also has the same point with Ferni's reflection about local curriculum. Therefore, through the reflection, the teachers recall their memory step by step of their teaching practice with technology and mention what they have learned dealing with technology as the media in the teaching process. As predicted in the literature by Farrell (2018), the teacher grows their understanding by describing and elaborating their instructional process that happened in class will develop their understanding of teaching with technology. Describing and elaborating the process is also a useful step for the next successful application of knowledge (Farrell, 2018). Further, by noticing the words ' $I$ have to consider that making a video in a simple thing' as a narrative implied the complexity of technology toward pedagogy knowledge. Technology affects on teacher's strategy in order to be understandable.

The third thing is after surveying the effective way of technology usage in a model lesson, the participants were capable of articulating their experience of technology adoption by narrating their findings orally in the interviews. Both of the all participants insisted upon the helpfulness of creating reflective journals. They explained that reflection is a media to recall everything they observed in classroom and to reflect on how to implement what they learned or plan for their future classroom. For example, Leni said," so because the journal is in written form, I can reread it. I found that I lack knowledge in this matter. I am planning, or less trying, less brave. Those are the benefits". Leni also reported that by writing more about their classroom experience, their views or their problems, reflection became even more analytical and profound in her class experiences.

The reflection is useful for helping me remember what happened in class until the next days. It feels fresh every day, so it helps me to be aware of problems or possibilities in integrating technology and materials. For example, I look back and learn the portfolio I made. Moreover, we do not need to repeat the problem we faced last semester because we can learn it from the reflective journal. For example, "I got the problem in these materials to be combined with this application," or when my students forgot to bring a charger for their class last week, I can remember it through reading the reflective journal. Then if there is a teacher change when I can not teach in class, it looks like it is useful too. (Leni, 2019).

Further, Leni explained that he could learn the problem from a reflective journal. She mentioned her problem with the material integration to the application media or the technology. It belongs to content and technological knowledge (TCK) problem. Another challenge faced by Leni is about students' readiness by pointing to the students who forget to bring a charger, it is reported that reflective practice indicates that the teacher must deal with any challenge and can evaluate whether he/she has given the meaningful change of learning by reading the reflective journal. Syahputri (2019) states Reading is central to the learning process. By reading activity, people may gain important that is not presented by teachers in the classroom. The reader is an active participant who has an important interpreive function in the reading process.

The findings revealed that by writing a reflective journal, the participants can remember what has been done during the implementation of the TPACK framework and pushed them to think about what happened in the classroom in-depth. Sometimes the teacher found some obstacles, whether it is a technical and non-technical problem (Drajati et al., 2018). This also relates to literature, which mentions about writing reflective journals narratively helped the 
teachers to be confident to do their actions in the classroom (Ford, 2016). This situation also relates to Farrell (2018), who reported that the goals of being a reflective teacher are constructing new learning based on the previous experience and introspection to the previous learning. Moreover, this will lead them to practical use in the future. In findings, one of the participants telling about "not repeating the problem in the future," as the future indicates the reflection mentioned by Schön (1983).

Besides to have a meaningful change in technology learning, by doing the group reflection, the teachers are more sensitive and aware, but also more open-minded and reflective in technology mediated teaching. Juna said:

Group reflection is useful. We can know and see other experiences from friends' experiences. For example, I use TED. Ed in other materials, not only what I thought before. Maybe something I do not know, I know it from the reflection activity. Then, besides knowing people's experiences, number two is exploring possibilities. "Oh, it turns out that it works like this?" "Oh, this is why getting a suggestion is not boring, just make a dialogue." I replace making video tips. How to find a solution for bullying, "oh yeah, that means giving suggestion does not have to be done, let us make it keep on collecting" but make tips, then the tips are posted on that. So it is possible. (Ferni, 2019).

In the above quotes, Ferni explained how their views evolved from group reflection. She gets many possibilities in applying technology to certain materials. She mentioned the materials about suggestion is always being taught conventionally, then after thinking about the possibilities told by her friends in the discussion, it turns out that she can accept the different way in teaching the materials. She thought that in-service teachers were required to have excellent skills in teaching English when they needed to apply 'teaching students' rather than 'teaching the materials.' Accordingly, Ferni shared his experience relating to improving his skill in teaching English by joining the reflective discussion both on social media or direct discussion. Another impact on writing a reflective journal and peer discussion stated by Ferni that she proved the aspect of open-mindedness by Dewey (1933). In her narrative, she has a desire to listen to many possibilities that happened in teaching with technology. Those possibilities involve the way, the source, and the impacts for the students. She thinks broader in teaching with technology. Just like the teachers expect students be active learners (Manning \& Payne, 1993; Randi, 2004), meanwhile teachers must also be involved throughout the teaching cycle, keeping an eye on the success of the course materials and listening to colleagues ' recommendations and input from students to refine their instructional materials and techniques.

From the above story, in-service teachers realized to teach students rather than teach the materials only. They needed to be aware of some aspects, not only technology, without considering many things. This statement relates to directness criteria as being a reflective teacher. By implementing directness, in-service teachers understood that they first should find out what aspect needed to be improved. In Kramarski and Michalsky's (2010) study, Metacognitive help for reflective questions supported pre-service teachers to track and assess their problem-solving processes; in addition, this encouragement enabled them to consider different viewpoints and principles for moving information from primary to high-order design skills, reflecting the development of PCK attendees.

The finding also the results also showed that meditation in their prospective classes encouraged the participants to talk on how to implement everything they acquired. From the interviews recorded, in this regard, the reflections mentioned by the participants were helpful for their learning. Based on Mouza (2011), the reflection did by the participants portrayed mostly descriptive reflection. In order to plan for the next lecture, it was important to go through those levels of reflection. The teachers have significant chances to apply in real- 
world curriculum of what they learned in the technology integration program, but time allocation, as revealed as the issue of reflection, made them think twice to apply it immediately. Thus, reflection, the act of creation, provided the teachers an opportunity to check in their thoughts about the concepts of technology integration they had learned in the workshop. Also, having played with the theories in her brain, IST-1 looked to be more comfortable in utilizing technology to instruct. Lee (2010) have observed that conducting reflective journals enables teachers become more confident in teaching. This phenomenon also happened to EFL novice The results of the first hypothesis testing show the social intelligence of the experimental group children taught through social simulsion learning strategies is greater than the social intelligence of the control group children who are taught not through social simulation learning strategies, with the average social intelligence of children $(\bar{X}=79)$ greater than the average social intelligence of children does not go through social simulation learning strategies $(\bar{X}=62.3$ ).

Based on a simple correlation calculation $\mathrm{rx}_{1} \mathrm{y}=0.675$, then the significance test is calculated, then the $t_{\text {count }}$ is obtained $=3.29$ while the value of $t_{\text {table }}=1.76$ at $\alpha=0.05$. Thus the $t_{\text {count }}$ is greater than the table value, which is $3.29>1.76$. This means that the variable $\mathrm{Y}$ with respect to $X_{1}$ is meaningful. It can be concluded that there is an influence of social simulation learning strategies in increasing social intelligence. Furthermore, the coefficient of determination of $\mathrm{Y}$ over $\mathrm{X}_{1}$ is $45.60 \%$. So it can be concluded that the influence of social simulation learning strategy variables on social intelligence is $45.60 \%$ while the remaining $54.4 \%$ is determined by other factors or variables.

This shows that the social simulation learning strategy has proven to be effective in increasing the social intelligence of Raudhatul Athfal Jamiyatushalihin Medan children. These findings indicate that to improve children's social intelligence it is more appropriate to use social simulation learning strategies as an experimental group than ordinary learning in the control class.

This is in line with the statement of Sudjana (2002: 89) that the simulation learning strategy is as a way to explain a lesson material through acts that are mocked or through a process of imitation behavior or play a role regarding a behavior that is carried out as if in a state which is actually.

This is also in line with Mudjiono's and Dimyati's (2002: 80) explanations which suggest the purpose of using social simulation learning strategies in learning activities, namely: (1) developing certain attitudes and skills, both professional and for everyday life. Train students to solve problems by utilizing available resources, (2) solve problems, (3) improve on concepts and principles that have been learned.

Furthermore, the advantages of social simulation learning strategies are explained as follows: (1) simulations can be used as provisions for students in dealing with the actual situation later, both in family life, society and in the world of work, (2) simulations can develop student creativity, because through simulation students are given the opportunity to play a role in accordance with the topic being simulated, (3) simulations can foster student courage and confidence, (4) enrich the knowledge, attitudes and skills needed in dealing with various problematic social situations, and (5) simulations can increase students' passion in the learning process.

The results of the second hypothesis testing showed that the speaking of the experimental group children taught through social simulsion learning strategies was greater than the speaking of the control group children who were taught not through social simulation learning strategies, with the average child speaking $(\bar{X}=83.3)$ greater than average children speak not through social simulation learning strategies $(\bar{X}=64)$. 
Based on a simple correlation calculation $\mathrm{rx}_{2} \mathrm{y}=0.724$, then the significance test is calculated, then the $t_{\text {count }}$ is obtained $=3.78$ while the value of $t_{\text {table }}=1.76$ at $\alpha=0.05$. Thus the $t_{\text {count }}$ is greater than the value of $t_{\text {table }}$ that is $3.78>1.76$ this means that the variable $\mathrm{Y}$ with respect to $\mathrm{X}_{2}$ is meaningful. So it can be concluded that there is an influence of social simulation learning strategies in improving speech.

Furthermore the coefficient of determination of $\mathrm{Y}$ over $\mathrm{X}_{2}$ is $52.50 \%$. So it can be concluded that the influence of social simulation learning strategy variables on speaking is $52.50 \%$ while the remaining $47.5 \%$ is determined by other factors or variables. This shows that the social simulation learning strategy is proven to be effective in improving speaking of Raudhatul Athfal Jamiyatushalihin Medan children. These findings indicate that to improve children's speaking it is more appropriate to use social simulation learning strategies as an experimental group rather than normal learning in the control class.

This is also in line with the statement of Khadijah (2017: 128) that the way to stimulate verbal-linguistic intelligence to grow optimally is through speaking, listening, reading, writing, discussing and telling stories. All these activities are included in the social simulation learning strategy. Furthermore, in this regard Dawson (1963: 29) explains about speaking children as follows:

1. Speaking is usually learned through listening and imitating. Therefore, examples or models that are listened to or recorded by the child are very important in mastering speech skills.

2. The words that the child will use and learn are usually determined by the stimulants they encounter (such as rural or urban life) and the words that provide the most help or service in conveying their ideas or ideas.

3. The child's speech reflects the use of language at home and in the community where he lives. For example, speech, intonation, vocabulary, use of words, and sentence patterns.

4. Younger children can understand sentences that are much longer and more complicated than sentences they can say.

5. Improving listening skills means helping to improve the quality of one's speech.

6. Sound or sound is an important factor in improving the use of the child's words. Therefore the child will be helped if they listen to the good utterances of the teachers, quality recordings, stories of high value, and so on.

7. Talking with the help of visual aids will result in better capturing information on the part of the listener. Generally, the child uses or imitates the language he hears.

The third hypothesis testing there is the influence of social simulation learning strategies in improving social intelligence and speaking together in children. When seen the results of testing the first hypothesis shows the social intelligence of the experimental group children taught through social simulation learning strategies is greater than the social intelligence of the control group children who are taught not through social simulation learning strategies, with an average social intelligence of children $(\bar{X}=79)$ more greater than the average social intelligence of children not through social simulation learning strategies $(\bar{X}=62.3)$.

Likewise, if the results of the second hypothesis testing show that speaking of the experimental group children who are taught through social simulation learning strategies is greater than speaking of the control group children who are taught not through social simulation learning strategies, with an average of children's speaking $(\bar{X}=83.3)$ greater than the average speaking child does not go through social simulation learning strategies $(\bar{X}=$ 64). 
This shows that the social simulation learning strategy has proven to be effective in increasing social intelligence and speaking of Raudhatul Athfal Jamiyatushalihin Medan's children. These findings also show that to improve social intelligence and speaking children are more appropriate to use social simulation learning strategies as an experimental group than normal learning in the control group class.

Based on the calculation of the multiple correlation $\operatorname{Rx}_{1} x_{2} y=0.729$, then the double correlation hypothesis testing is done using the $\mathrm{F}$ test, then the $\mathrm{F}_{\text {count }}=12.1$ is obtained while the $F_{\text {table }}=4.67$ at $\alpha=0.05$. Thus the $F_{\text {count }}$ is greater than the $F_{\text {table }}$ value which is $12.1>4.67$. Then it can be concluded that there is an influence of social simulation learning strategies in increasing social intelligence and speaking together in children in Raudhatul Athfal Jamiyatushalihin Medan.

\section{Conclusion}

The conclusions that can be drawn from the results of hypothesis testing are as follows:

1 The average results of children's social intelligence Raudhatul Athfal Jamiyatushalihin Medan experimental group taught by social simulation learning strategies is greater than the average results of the children's social intelligence control group. Thus the social simulation learning strategy is more effectively applied in learning the development of social aspects in order to improve children's social intelligence.

2 The average speaking results of Raudhatul Athfal Jamiyatushalihin children Medan experimental group taught by social simulation learning strategies is greater than the average results of the social intelligence of the control group children. Thus the social simulation learning strategy is more effectively applied in the development of language aspects of learning in order to improve children's speaking intelligence.

3 The average results of social intelligence and speaking of the experimental group children who showed a significant increase compared to the increase produced by the control group, it can be concluded that the influence of social simulation learning strategies not only increase children's social intelligence or vice versa not only improve children's speaking, but jointly able to improve both, in other words the average social intelligence is directly proportional to talking and vice versa. A good kid's socialization also indicates a good ability to speak. Likewise, children who have good speaking skills will be easily accepted by their environment in socializing.

Furthermore, suggestions that can be given are:

1. To the Principal to motivate teachers in learning activities to implement social simulation learning strategies because through this research it is proven that social simulation learning strategies can improve social intelligence and speaking of children.

2. The teacher must always expand and add insight and knowledge so that they can hold a variety of social simulation activities, according to the theme. In addition, broadening horizons and generating bright ideas in creating social simulation game equipment such as making simulation game equipment from used goods and natural materials that are child friendly and using items that already exist in the school area as a means of infrastructure for social simulation activities and so forth. Whereas for children, teachers can involve children in making easy game equipment, for example making crowns and war hats using jackfruit leaves, because in the process of making and even then part of social simulations where children can interact socially with teachers and peers.

3. To other researchers who want to research more about social simulation learning strategies should pay attention to other variables so that more comprehensive knowledge is obtained. 


\section{References}

Ahmadi, Abu. Pengelolaan Pengajaran. Jakarta: Rineka Cipta, 1990

Ananda, Rusydi dan Muhammad Fadhli. Statistik Pendidikan Teori dan Praktik Dalam Pendidikan. Medan: Widya Puspita, 2018.

Brooks, Nelson. Language and Language Learning. New York: Harcourt Brace and World Inc, 1964.

Chaplin, J.P. Kamus Psikologi. Jakarta: Raja Grafindo Persada, 2004.

Dawson, Mildred A. et- a. Guiding Language Learning. New York : Harcourt Brace and World, Inc, 1963.

Dimyati dan Mudjiono. Belajar dan Pembelajaran. Jakarta : Rineka Cipta, 2008.

Hurlock, Elizabeth B. Perkembangan Anak. Jakarta: Erlangga, 1990.

Khadijah. Pendidikan Prasekolah. Medan : Perdana Publishing, 2017.

Moeslichatoen, R. Metode Pengajaran di Taman Kanak-Kanak. Jakarta: Rineka Cipta, 2004.

Patmonodewo, S. Pendidikan Anak Prasekolah. Jakarta: Rineka Cipta, 2003.

Pratisti, WD. Psikologi Anak Usia Dini. Jakarta: Indeks, 2008.

Sudjana, Nana. Dasar-Dasar Proses Belajar Mengajar. Jakarta; Sinar Baru Algensindo, 2002.

Suparman, M. Atwi. Desain Instruksional Modern, Panduan Para Pengajar dan Inovator Pendidikan. Jakarta : Erlangga, 2012.

Tangyong, A. F. Pengembangan Anak Usia Taman Kanak-Kanak. Jakarta: Gramedia. 2009.

Tarigan, Henry Guntur. Berbicara Sebagai Suatu Keterampilan Berbahasa. Bandung: Angkasa, 2008.

Undang-Undang Republik Indonesia No. 20 Tahun 2003 Tentang Sistem Pendidikan Nasional. Jakarta: Eka Jaya, 2003. 